\title{
The investigation of knowledge leadership in innovation performance of companies
}

\author{
Alborz Safari $^{1^{*}}$, Elham Ashuri ${ }^{2}$ \\ ${ }^{1}$ Department of Public Management, Islamic Azad University, Rasht, Iran \\ ${ }^{2}$ Department of Public Management, Islamic Azad University, Rasht, Iran \\ E-mail address: *Alborzsafari@gmail.com, Elham.ashurii@gmail.com
}

\begin{abstract}
Keywords: knowledge leadership, innovation performance, commercial and manufacturing companies
\end{abstract}

\begin{abstract}
Knowledge leadership is essential for organizations focused on intensive technology in order to improvement of innovation performance through the effective development and implementation of performance of knowledge management. Knowledge leadership as a driving force for knowledge management measures that are indirectly linked with innovation performance. In fact, the more leadership is broader, more developed knowledge management practices, which in turn affects the performance of innovation. According to to the increasing demand for knowledge and activities to integrate knowledge, innovation can promote exchange and interaction between people, thus leading to joint activities of knowledge management and innovation performance.
\end{abstract}

\section{INTRODUCTION}

International organizations based on the principles of knowledge management, development and implementation its plan to improve the effectiveness of business processes, increase productivity and quality of their service and find solutions and new products for their customers. In this regard, another important factor is leadership style and behavior that has a significant impact on the direction and effectiveness of knowledge management in organizations (Mohamed \& Nguyan, 2011). Companies can use knowledge leadership to develop knowledge management practices and to improve the willingness of employees in their innovation performance. Managers should establish the ideal contextual conditions to propel and optimize the organization's use of knowledge management practices and initiatives through the design of tools such as human resource management practices (Lin, 2011).

Knowledge leadership is essential for technology-oriented organizations. It is an approach that is rapidly developing and attention to improve the effectiveness of processes, along with continuous innovation. Needing to knowledge leadership, derives from the fact that the knowledge practices on the innovation performance and access to sustainable competitive advantage is considered an important act. Indeed, leadership is as an essential condition for the development and knowledge management practices to encourage innovation objectives focuses on technologyintensive companies. In this regard, knowledge leadership is as a leadership issues and companies are considered successful that give more value(Donate and de Pablo, 2014).

Innovation performance is combination of overall success of the organization in order to modernize and improve the result of the efforts made and the implementation of various aspects of innovation in the organization. In the literature, innovation performance is one of the most important drivers of other functional aspects of the organization regarding to the continuous efforts to improve, renew, exploration, learning from mistakes, compromise the competitive environment to quickly (Gunday et al., 2011). This concept can be achieved through exploratory innovation by reform of existing knowledge and skills development, customer needs and occur respond to environmental conditions ( $\mathrm{Zhou} \& \mathrm{Wu}, 2010$ ). Innovation performance help to new product and process in organizations and considered as a competitive advantage (Xu \& Li, 2009). It is critical for companies to remain competitive and successful way to compete with market changes. The higher performance of enterprise innovation activities be related. Successful innovation can help 
companies achieve greater profits (Martinez, 2014). Innovation performance is obtained for product development and new manufacturing processes or improving existing processes (Moradi et al., 2013).

Adopting new behavior and new idea or innovation to be taken in order to function (Tamay -Torres et al., 2010). Innovation performance is will often appear with the number of achievements, records and reports new projects that take part in routine work is claimed, will be displayed. Also, the quality of new products and new processes with rival represents the company's innovation practice (Hung, 2011). Companies quickly adapt to changes made possible through innovation performance created and are protected against environmental instability with regard to performance, profit increased their market participation (Zehir et al., 2012). Given the importance of weakness in innovation performance of manufacturing and commercial companies can be a unwillingness introduction of new products or services and the introduction of new process, not having respond quickly to introduce new competitive process, lack of adequate training for new service innovation and reduce the number of products offered in the market ( Kazazi \& Scholl, 2013).

Knowledge leadership is defined as any attitude or action- joint or individual, observed or imputed- that prompts new and important knowledge to be created, shared, and utilized in ways that bring a shift in thinking and collective outcomes. (Mabey et al., 2012). knowledge leadership implies role of knowledge management practices of companies in order to realize the opportunities for innovation (Donate \& de pablo, 2014). Leaders must act as a advisor so that employees can recognize how knowledge management practices and job help them guaranty communications. Communications is vital for leaders to clearly show their expectations of the company and eliminate communication barriers (Schermehorn, 2012).

In this research, knowledge management practices are included two dimensions. Knowledge creation, it means that makes a stronger commitment in $\mathrm{R} \& \mathrm{D}$ activities and are useful for creative learning experiences (Von Krogh et al., 2012). Application knowledge should focus on the integration and use of knowledge for organizational activities and solve problems more easily and effectively (Zack et al., 2009).

Knowledge leadership behavior and innovation performance regarding to knowledge management practices is necessary for technology intensive organizations in order to improvement of innovation performance through development and implementation of knowledge management practices. Knowledge-oriented leadership as a driving force for knowledge management measures that are indirectly linked with innovation performance. In fact, the leadership is broader knowledgebased company, has developed knowledge management practices, which in turn affects the performance of innovation. (Donate \& De pablo, 2014).

According to background conducted similar studies in the field have been the subject of research. Mohammadi Hossieni and et al (2013) conducted a study titled on the role of organizational learning in innovation performance increased. The effect of organizational learning and impact on innovation performance in enhancing the innovative performance elements of learning has taken place.

The population of the investigation are all supervisors and employees Industrial Co. Caspian seal is the sample number is 400 people, according to Morgan, and the results have a positive impact, direct and meaningful innovation performance of showed learning . Khalifeh Soltani et al (2010) examined the role of leadership in increasing the effectiveness of their knowledge management practices. The survey among 950 executives Iranian Oil Products Distribution Company in which 270 people were selected. The results showed a direct relationship between leadership styles with the creation and sharing of knowledge was performed. Effect of modulators on shared leadership and innovation performance significantly. Donate and De pablo (2014) as the leading knowledge-based research on knowledge management and innovation activities carried out The study consisted of 802 senior managers of the company in Spain that the sample of 111 questionnaires. The results showed that knowledge management practices as a mediator role in the relationship between the leadership, knowledge-oriented and innovation performance. 


\section{LITERATURE REVIEW}

\section{Innovation performance}

The process of innovation performance in the application of new or improved services and delivery of products or technology to increase efficiency is concerned and in terms of the introduction of new or significantly improved process will be measured. Innovation performance according to the introduction of new methods or improve existing methods of how to work, how to organize and establish the effectiveness and efficiency of defined channel foreign cooperation to increase the company's internal operations. According to the introduction of new or improved organizational innovation performance in job training or internal knowledge sharing, flexible work, supply management or the management of production, output specific tasks and relationships with suppliers, customers or government measured. Marketing innovation performance is referred to introduce new or improved methods that help to the effectiveness of the service or cognition customers in terms of sales and marketing (Cho et al., 2011). Today, companies that focus their innovation performance, market share and profits to significantly increase (Moradi et al., 2013).

\section{KNOWLEDGE LEADERSHIP}

Knowledge leadership rather than the position of the association focused, innovative learning processes and of the influence of subjective knowledge exchange, implicit and explicit support over time (Peet, 2012). Knowledge leadership is defined as the process by which individual members of other groups supporting the learning cycle needed to achieve the goals of a group or organization. Knowledge leadership may develop mechanisms to respond and control the sharing of knowledge with customers to help. Knowledge-oriented leadership is defined as the process by which individual members of other groups supporting the learning cycle needed to achieve the goals of a group or organization. Leadership development mechanism for accountability and control possible knowledge sharing with customers help (Yang et al, 2014). The emergence of knowledge led to conflicts parametric range can be aligned field. The term knowledge management, has been established in the past two decades. The researchers acknowledged that the concept of a knowledgeoriented leader in the true sense is not very well known. This type of leadership as a new paradigm for the entire field of knowledge management has been proposed. In most cases, it can be argued as an alternative view to managing and understanding until the new base for general principles (Huvila, 2014).

\section{DISCUSSION AND CONCLUSION}

According to the findings, it can be said as the impact of knowledge on innovation performance was confirmed, managers of companies, with a certain type of knowledge-oriented leadership for development and improvement of technology regarding to R\&D activities and convenient use of technology help innovation performance. Company's investment can effect on R\&D activities and experienced unit in order to development and improvement of technology.. Also, access to relevant information and key knowledge and use of scientific knowledge used and the integration of different groups can lead to innovation performance. Managers by organizing knowledge and its application and use in different units from offer customers, vendors can play an important role in the application of knowledge. According to the analysis of the results showed that knowledge-oriented leadership has effect on knowledge creation. Because of weaknesses in the management of knowledge and innovation, leadership duties conform at issue in the assessment and external knowledge sharing and stored faced by managers.

Commercial and manufacturing companies can help to individuals who operate in R\&D activities through investment absorption in market. Since the findings of the study showed that the use of effective leadership, knowledge, managers should seek to establish a working group of experts from the sub-units of information terminals that if the problems encountered to help them through the integrated application of knowledge the knowledge to be solved. Companies consider 
new ideas and changes, increasing their capacity to use scientific background to be able to have a sustainable competitive advantage over competitors in the innovation performance. According to analysis of the impact of research findings on innovation performance knowledge-oriented leadership was confirmed. Also, managers can plan using appropriate knowledge and learning through visual learning on how to do rival's products improvement. Manufacturing companies will also have to take advantage of new ideas to think about delivering products in accordance with the wishes and demands of their customers, and if otherwise, they can't compete with rivals.

\section{CONCLUSION}

Knowledge leadership as a driving force for knowledge management measures that are indirectly linked with innovation performance. In fact, the more leadership is broader, more developed knowledge management practices, which in turn affects the performance of innovation. According to to the increasing demand for knowledge and activities to integrate knowledge, innovation can promote exchange and interaction between people, thus leading to joint activities of knowledge management and innovation performance.

\section{References}

[1] Boroomand, M; Ranjbari, M.(2009). Strategic practices of human resource management and innovation performance: with emphasis on knowledge management role, Journal of human development, sixth, N24, pp.21-52.

[2] Cho, I; Park, H; Choi, J. The impact of diversity of innovation channels on innovation performance in service firms , Serv Bus 5, Issue 3:, pp 277-294, 2011.

[3] Donate,J,M, Jesus D. Sánchez de Pablo. (2014)The role of knowledge-oriented leadership in knowledge management practices and innovation, Journal of Business Research, Volume 68, Issue 2, February, Pages $360-370$.

[4] Gholamreza, Kh (2010). Research methodology in management. Center of scientific publications Islamic Azad university.

[5] Gunday, G., Ulusoy, G., Kilic, K., \& Alpkan, L. (2011). Effects of innovation types on firm performance. Int .J .Production Economics, 133, 662-676.

[6] Huvila , I ( 2014). Towards information leadership, Aslib Journal of Info Mgmt, 66, 663-677.

[7] Hung, R. Y. Y., Lien, B. Y. H., Yang, B., Wu, C. M., \& Kuo, Y. M.( 2011). Impact of TQM and Organizational Learning on Innovation Performance in the High-Tech Industry. International Business Review, 20(2), 213-225.

[8] Khalife soltani, H; Hosseini,M, Asgari, N. (2010). Empowerment leadership style of knowledge management, Human resource quarterly university of Emam Hossein university, second year, N 2and3, pp. 149-166.

[9] Kazazi, A; Shol,A. (2013). The impact of TQM on innovation performance. Moderator role of organizational learning. Scientific research of management studies quarterly, N 71,pp.1-17.

[10] Lin, H. F. (2011). The effects of employee motivation, social interaction, and knowledge management strategy on KM implementation level. Knowledge Management Research \& Practice, 9(3), 263-275.

[11] Moradi, M; Valipoor ,Y ; Keykhosro, S. Abdollahiyan, F. (2013). Investigation of role of knowledge absorbsion capacity on innovative performance of organizations(Case study, pharmaceutical and insurance companies in Tehran).Journal of outlook business management, N13,pp. 10-79. 
[12] Mohammadi, A; Amin bidokhti, A; Jamshidi, Laleh.(2014). Investigating role of organizational learning in increasing of innovation performance, Journal of innovation and value creation, N4,pp. 84-95.

[13] Mabey, C., Kulich. C. \& Lorenzi-Cioldi. F. (2012) Knowledge leadership in global scientific research, The International Journal of Human Resource Management, 23(12), 2450-2467.

[14] Martínez, F.J. Diaz-Garcia, C. and González-Moreno, A(2014). Environmental Orientation as a Determinant of Innovation Performance in Young SMEs, Int. J. Environ. Res., 8(3):635642,Summer ISSN: 1735-6865.

[15] Nikookar, Gh; Asgari, N; Gholami,M; Rahimi, E (2014). Role of intellectual capital in facilitating of knowledge management practices and public management N2, pp. 401-418

[16] Peet, M. (2012) Leadership transitions: tacit knowledge sharing and organizational generativity. Journal of Knowledge Management, 16, 25-60.

[17] Schermerhorn, J. R.. Management (11th ed.). John Wiley \& Sons: New York, 2012.

[18] Shakeri,F,Mehrjoodi, M,H; Dehghan Dehnavi, H.(2010). Investigation of relationship of organizational atmosphere and innovation in process. Journal of scientific research of production and operational management N1, pp. 29-46.

[19] Tamayo-Torres, I. (2010). The moderating effect of innovative capacity on the relationship between real options and strategic flexibility. Industrial Marketing Management, Vol. 39, pp. $1120-1127$.

[20] Tarivardi, Y; Damchi jelodar,Z.(2011). The relationship of risk management and performance of company, Journal of finanacial accounting and auditing. forth, N4, pp. 43-62.

[21] Yang, P.Y. and Chang, Y.Ch. (2010). Academic research commercialization and knowledge production and diffusion: the moderating effects of entrepreneurial commitment. Journal of Scientometrics, 83(1): 403-421.

[22] Yang,L, C- Huang, T Hsu.(2014). Knowledge leadership to improve project and organizational performance, International Journal of Project Management 32,40-53.

[23] Ying, H, M; Jian-peng ,W. (2013). The Impact of Shared Leadership on Innovation Performance, International Conference on Management Science \& Engineering (20th) , Harbin, P.R.China pp 1385 - 1390.

[24] Zehira,C, Oznur Gulen Ertosunb, Zehirc,S, Müceldilli,B. (2012). Total Quality Management Practices' Effects on Quality Performance and Innovative Performance, International Conference on Leadership, Technology and Innovation Management, Procedia - Social and Behavioral Sciences $41273-280$.

[25] Zhou, K. Z., \& Wu, F.( 2010). Technological capability, strategic flexibility, and product innovation. Strategic Management Journal, 31(5): 547-561. 